\title{
Ольга Царик,
}

доктор педагогічних наук, профессор

кафедри іноземних мов та інформаційно-

комуннікаційних технологій,

Тернопільський національний економічний університет

(м.Тернопіль, Україна)

\section{Olha Tsaryk,}

doctor of pedagogical sciences,

professor of the foreign languages department,

Ternopil National Economic University

(Ternopil, Ukraine)

tsarykolga@gmail.com

ORCID ID 0000-0003-0169-7009

Web of Science Researcher ID H-3258-2017

\section{Наталія Рибіна,}

кандидат філологічних наук, доцент кафедри іноземних мов та інформаційнокомуннікаційних технологій,

Тернопільський національний економічний університет (м.Тернопіль, Україна)

\section{Nataliia Rybina,}

candidate of philological sciences,

associate professor of the foreign languages department, Ternopil National Economic University

(Ternopil, Ukraine)

nataliarybina@ukr.net

ORCID ID 0000-0001-6260-9039

Web of Science ResearcherID G-9745-2017

\section{Жанна Баб'як,}

кандидат педагогічних наук, доцент, завідувач кафедри української та іноземних мов та інформаційно-комуннікаційних технологій Тернопільський національний технічний університет ім. І.Пулюя

(м.Тернопіль, Україна)

\section{Zhanna Babiak,}

candidate of pedagogical sciences, associate professor, head of the Ukrainian and foreign languages department, Ternopil Ivan Puluj National Technical University (Ternopil, Ukraine)

b.janna73@gmail.com 


\section{СТРУКТУРНО-ПРОЦЕСУАЛЬНА МОДЕЛЬ МОТИВАЦІЇ НАВЧАЛЬНОÏ ДІЯЛЬНОСТІ СТУДЕНТІВ STRUCTURAL PROCEDURE MODEL OF STUDENTS'
EDUCATIONAL ACTIVITIES MOTIVATION}

Анотація. У статті розглянуто модель мотивації навчальної діяльності студентів крізь призму її структури та процесу актуалізації. Авторами визначено теоретико-методичні аспекти формування зазначеної моделі, а також здійснено термінологічний аналіз основних композитів зовнішньої та внутрішньої мотивації; зазначені стратегічні умови реалізації потенціалу студента в процесі професійної підготовки у закладі вищої освіти. У статті доведено, що внутрішня і зовнішня мотивація навчальної діяльності є структурно неоднорідними, що відрізняються за структурою зв'язків з академічними досягненнями і психологічним благополуччям, в основі яких лежать базові психологічні потреби студентів. Водночас, виразність мотиваційних складових навчальної діяльності визначається особливостями освітнього середовища, рівнем її складності, мірою задоволення в ній базових психологічних потреб.

У результаті дослідження було встановлено, що мотивація навчальної діяльності включає свідомі та несвідомі причини, які спонукають людину здійснювати навчальну діяльність, та зроблено висновок, що загалом, оскільки навчальна діяльність $€$ не лише інтелектуальною діяльністю, а й значною мірою соціальною, її оптимально функціонуюча мотивація - це поєднання внутрішніх та продуктивних форм зовнішньої мотивації, де ми приписуємо мотиви, які служать задоволенню основних потреб особистості, з домінуванням внутрішніх виховних мотивів. Автори наголошують, що важливим моментом є те, що здійснення заходів, регульованих внутрішньою мотивацією, дає відчуття радості та щастя, що $€$ ще одним аргументом на користь підтримки внутрішньої навчальної мотивації студентів. Унаслідок здійсненого аналізу було також доведено, що «мотивований» суб'єкт освітньої діяльності має цілу низку когнітивних характеристик, що забезпечують процеси постановки цілей, реалізацію намірів, планування діяльності, реагування на невдачі, прояв наполегливості, в сукупності призводять до високих результатів в виконуваної навчальної діяльності.

Ключові слова: навчальна діяльність, студент, мотивація, мотиви, структурно-процесуальна модель, когнітивні характеристики.

Introduction. The study of the reasons that make a person develop and improve himself is extremely important from the point of understanding the motivational process. This is the starting point from which the analysis of motivation begins. The educational process consists of complex types of activities, so there are many motives for learning. They can not be demonstated separately by each person, but also merge into a single one, forming complex motivational systems. In Ukraine students' interest in learning fades year by year. Entering universities, they have no idea why they are going there. Many of the students study only to obtain a diploma of higher education, while not getting the proper knowledge. In this matter, students can help self-motivation, as well as stimulation from teachers.

The objective of our work is to distinguish structural procedure model of students' learning activities motivation by analyzing the experience of the higher educational establishments of Ukraine.

Results of the study. By motives, we understand the reasons - both conscious and unconscious - of the ongoing activity, which are behind the needs and values of the individual's activity. Learning motives are an important component of motivation; they include conscious and unconscious reasons that encourage a person to carry out educational activities. It should be distinguished two main types of motives i.e. internal and external (in the case of educational activities - internal and external educational motives), which, due to their complex nature, are usually called internal and external motivation (E. Deci, R. Ryan, M. Lepper, H. Heckhausen). In case of internal motivation, the causes that give rise to this activity lie within the individual. Only the person himself is a source of motivation and the activity itself is of his own interest and values.

In case of external motivation, the individual focuses primarily on the result, and the activity itself is only a means to help achieve other goals that are important to him, but it is external to the content of the activity. Therefore, the concept of "external motivation" is used to describe different types of aspirations that stimulate the performance of activities not for its own sake, but for the rewards that give a high result in it e.g. to increase self-esteem, have reason for self-esteem or receive praise from significant people, awards, money etc. Internal and external motivations consist of motives correspondingly relevant to the content of educational activities (internal motives) or external to it, aimed at satisfying other related needs directly (naturally). According to the definition given by E. Deci: "Internally motivated activities have no other incentives than activity itself. People are involved in this activity for its own sake, and not to achieve any external rewards. Such an activity is an end in itself, and not a means of achieving some other goal" (Deci, 1975, p. 23). Most modern theorists, engaged in the problem of achievement motivation, agree that in order to achieve success, it is necessary to focus mainly on the process, and not on the result. Many authors argue that the main award received from achievement is not related to the attainment of the goal as such, but to work aimed at approaching it, that is, with the process itself. The subtitle of the biography of Steve Jobson, one of the founders of Apple Computer, is very noteworthy: "The award is the path itself." External motivation is understood as a phenomenon that is present when the factors initiating and regulating the activity are outside the individual (1) or outside the activity (2). In case (1), other people act as the main source of stimulation of the individual to carry out activities (offering rewards, awards, punishments, etc.), in case (2), the activity performed is a means of achieving other goals important for the individual, although he may be its initiator himself and he regulates its implementation himself as well. External 
motivation has many specific manifestations that have different psychological meanings and, accordingly, lead to different consequences for the success of the activity. Thus, the nature of external and internal motives governing the implementation of activities is an important characteristic of an individual's motivation. This component of achievement motivation is important for understanding (1) who (or what) is behind the implementation of this activity - he or other people and (2) if the activity is carried out of his own free will, is it interesting and brings him joy and satisfaction by itself or it is a means of achieving other important goals for the individual.

Basic needs for knowledge, achievement and competence that are primary to the learning outcome are in the centre of internal learning motivation. The pursuit of their satisfaction encourages the young person to learn, to make efforts, to bring the case to a close, to set ever more difficult goals, to enjoy their achievement and their own change, growth. On the other hand, external motivation is based on the secondary needs of the learning process i.e. the need for autonomy, respect, self-esteem and acceptance. Accordingly, there are three types of internal and six basic (basic) types of external learning motivation. Internal motivation of learning activity consists of three types of motives - cognitive, achievement and self-development. Their source, respectively, are basic human needs for cognition, creation (achievement of productive result) and competence (skill), which are inherent in all human beings and differing in insatiability. Cognitive motives are manifested in interest, enthusiasm, curiosity, the desire to learn new in the process of educational activity, it is accompanied by pleasure and a sense of joy in its fulfillment - from the process of understanding and knowing the new. The need for knowledge and understanding of the surrounding world is inherent in all human beings. Animals have got a specific (obviously the simplest) form of cognitive motivation, called orienting reflex by I. Pavlov, the essence of which is that the animal responds to a new stimulus by tuning receptors, as if trying to learn "What is it?". Aristotle noted that "By nature, people are gifted with the desire to know." "Children need not be taught curiosity. Children can only be weaned from curiosity, and it seems to me that this tragedy is unfolding in our kindergartens and schools," A. Maslow similarly notes (Maslow, 1999, p. 94). Indeed, psychological research shows that if the environment does not clog the natural curiosity of the child, it develops, acquiring new forms at different stages of development.

The achievement motives are manifested in the desire to make efforts and to achieve the best results in an area that the individual considers important and significant. Its importance as the basic human motivation is inextricably linked with the desire for creation and creativity. It manifests itself in a high level of involvement in the activity, the desire to bring the start to the end and show persistence. Achieving motivation is characterized by one's own desire to exercise activity because of its importance and long-term meaningfulness for the subject of activity. On the material of educational activities, the motives for achievement may be sufficiently broad, generalized, or, in practice, much more specific, specific in nature with respect to particular disciplines. Adults manifest this motivation in the desire for creation, creativity and discovery for the sake of the progress of society, for the improvement of other people's lives.

The third type of motives that are inherent in the internal motivation of the learning activities is self-development motives, which are based on the need for competence, skill, growth and self-improvement. The motivation for selfdevelopment is characterized by the desire to develop the skills and competence, to change yourselves for the better. According to developmental learning theorists V. Davydova and G.Zuckerman, it should be the basis of higher education.

Thus, the components of this motivational triad have a different focus: cognitive motives are directed to the process of knowledge and understanding of the world, the achievement motives - to the creation and fulfillment of a well-defined case and the motives of self-development - to gain competence, skill, perfection of one's own skills and abilities. This specificity leads to varying degrees of their expression in ontogeny at different stages of student's development. For each young person these three types of external motives can form a unique profile, so it is necessary to speak not only about their expressiveness, but also about their hierarchy.

External motives include five main types, which can be subdivided into two large subgroups, the basis of which is the satisfaction or frustration of basic psychological needs. The separation of the two groups is relatively conditional, since the existing types of motives are rather a continuum, at one end of which there is a satisfaction of the basic needs of the subject of activity, at the other - their frustration. This measure of frustration also sets a measure of the effectiveness (productivity) of the motive in terms of the success of the activity performed and the psychological well-being of the subject. Motives that initiate educational activities (while meeting basic needs) tend to have a favorable effect on its success and have no negative consequences for the psychological well-being of the subject, because as a result of the fulfillment of its needs are met. (This is why stimulating competitive motivation can have a positive effect on performance and not reduce psychological well-being. (For example, this can happen if the subject perceives the competition as an opportunity to raise their self-esteem, to gain recognition and respect from significant others), triggering educational activities through frustration of basic needs lead to a decrease in the effectiveness of the activity and at the same time to a decrease in psychological well-being. The energy, attention, strengths of the subject of activity in this case as if split, as the student is forced to simultaneously fight for the result of the performed activity and to experience frustration of basic needs, disturbed control of his activity from the outside. Thus, competitive motivation can have negative consequences for the weak student in terms of the success of the activity, which degraded its outcome, and in terms of psychological well-being, causing anxiety), which is defeated if the competition is perceived as an incentive, undermining self-esteem, forcing him to fight for goals that are not close to him. In terms of educational activities, the first subgroup of external motives includes two main types of motives: self-esteem motives for achievement and competence when learning activities are driven by the desire to prove oneself the ability to cope with the task and the motives of respect for others; 
the desire to learn for the sake of gaining respect and recognition of significant others (parents, teachers, peers). The second subgroup of external motives, based on frustration of the basic needs of the subject of activity, consists of the following three types of motives: 1) motives of the need for autonomy which are inherent in nature, based on absorption of external requirements of the environment and regulating the performance of activities mainly due to feelings of guilt and shame in front of themselves and the closest environment; 2) motives of overcoming the frustration of the need for competence, which appear to be motivation for subordination to the demands and will of other people who have power over the young person, who control his behavior through rewards, orders, criticism; 3) motives of overcoming the frustration of the need for acceptance (for example, as a reaction to the behavior of parents who show conditional love to the child, depending on his or her marks, thereby trying to induce him not to receive bad marks, to engage more, not to miss the classes, etc.

The results of this dependency is demonstrated in Fig. 1.

It should be noted that this classification does not include motives that are uncertain or neutral in terms of the subject's needs. Among them there may be the desire to study for the sake of obtaining a high mark, admission to a post-graduate studies, obtaining a high-paying job. A subject can strive for these goals for various reasons, driven by substantially different motives, such as striving for self-development, a desire to help other people, satisfy the demands of parents, or increase self-esteem.

However, if one does not understand the meaning behind this desire, it is impossible to determine its importance for the effectiveness of the activity and in particular the educational activity (as well as psychological well-being). On the whole, it can be argued that learning activity based on basic needs will demonstrate more positive relationships with success than based on frustration and, accordingly, regulated by the threat of punishment, external control, and the fear of losing the love of parents.

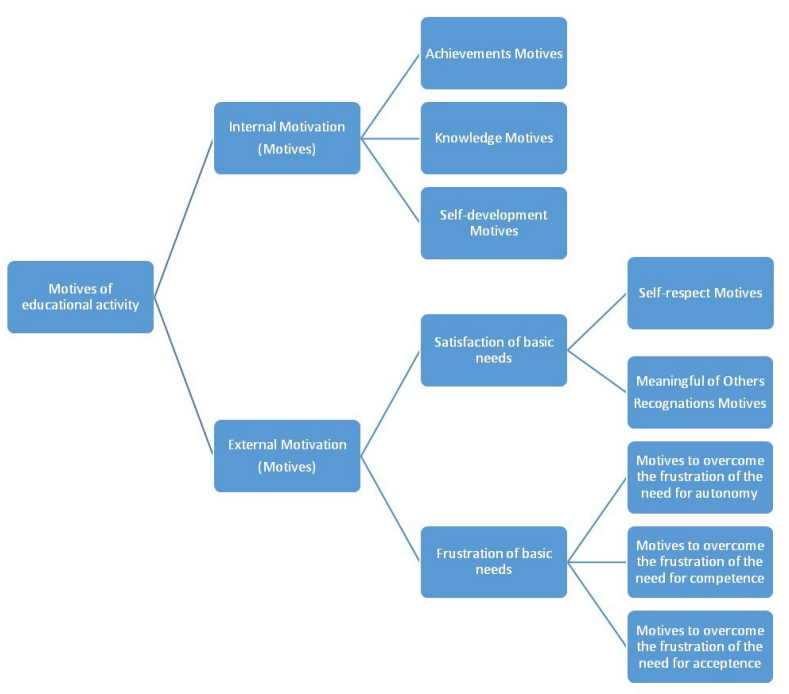

Fig. 1. The model of learning motives

This typology of educational motives helps us to solve the following current problems of educational activities. Firstly, in fact, the problem of confronting internal and external motivation or more precisely, internal and external motives for activity coexisting with each other, forming different patterns or profiles. Secondly, there is a problem of different degree of efficiency in educational activity of students with different motivational profiles in different educational environments. Psychological studies confirm that gifted individuals have a specific feature of motivation that is a significant dominance of internal motivation over external one. This is manifested in genuine interest, involvement in the activity primarily for its own sake, because it is perceived as valuable and interesting, which leads to a willingness to engage in a long and systematic way (Bloom, 1985). The activity they carry out has a distinct personal meaning: gifted people are convinced of the need and the utmost importance of the work being done and write because they cannot not compose, paint pictures, as well as they can not write poems, etc. An internal interest in the activity may be accompanied by indifference and external rewards, glory, but the predominance of external motivation, as a rule, adversely affects the quality of the activity, especially in the case of activities that require pronounced mental activity and creative efforts.

The optimal option for the functioning of the achievement motivation for activity includes dominating the interest in the structure of the subject's motivation, accompanied by the pleasure of its implementation and understanding of its importance and meaning, as well as a sense of competence and control. The optimal functioning of achievement motivation also includes the prevalence of an individual's internalized external motives compared to such regulators of activity as external motivation, guilt, or competitive motives. In this case, the individual consciously forces himself to work, shows volitional regulation of activity, since its result is important for the student. In the optimal case, a person 
performs accomplishment activity (educational, labor, etc.) because it is important and interesting for him. On the contrary, non-adaptive or neurotic functioning is based on the prevalence of the individual non-specific motives of productive activities such as the desire for power, orientation to external recognition, financial success, ratings, fame, which are mostly external ("I must do this, otherwise the punishment will follow") and introverted ("I must do this so as not to feel guilty") regulation of activity with a low level of internal motivation.

Conclusions. So educational activities motivation includes conscious and unconscious reasons that encourage a person to carry out learning functioning. These motives (motivation) can be either internal or external. In general, since educational activity is an activity not only intellectual, but also largely social, its optimally functioning motivation is a combination of internal and productive forms of external motivation, where we attribute motives that serve the satisfaction of the basic needs of the individual, with the dominance of internal educational motives. An important point is that the implementation of activities, regulated by internal motivation, gives a feeling of joy and happiness, which is another argument in favor of supporting students' internal educational motivation.

\section{REFERENCES}

Burton, K.D., Lydon, J.E., D'Alessandro, D.U., \& Koestner, R. (2006). The differential effects of intrinsic and identified motivation on well-being and performance: Prospective, experimental and implicit approaches to self-determination theory. Journal of Personality and Social Psychology, 91, 750-762.

Deci, E.L., \& Ryan, R.M. (2008a). Facilitating optimal motivation and psychological well-being across life's domains. Canadian Psychology, 49, $14-23$.

Deci, E.L., \& Ryan, R.M. (2008b). Self-determination theory: A macrotheory of human motivation, development and health. Canadian Psychology, 49, 182-185.

Gottfried, A.E., Fleming, J.S., Gottfried, A.W. (2001). Continuity of academic intrinsic motivation from childhood through late adolescence: A Longitudinal study. Journal of Educational psychology, 93, 3-13.

Helmreich, R.L., Beane, W.E., Lucker, G.W., \& Spence, J.T. (1978). Achievement motivation and scientific attainment. Personality and Social Psychology Bulletin, 4, 222-226.

Ratelle, C.F., Guay, F., Vallerand, R. J., Larose, S., \&Senecal, C. (2007). Autonomous, controlled, and amotivated types of academic motivation: A person-oriented analysis. Journal of Educational Psychology, 99, 734-746.

Snyder, C.R., Shorey, H.S., Cheavens, J., Pulvers, K.M., Adams, V.H., Wiklund, C. (2002). Hope and Academic Success in College. Journal of Educational Psychology, 94(4), 820-826.

Sokolowski, K., Schmalt, H.-D., Langens, T., \&Puca, T. (2000). Assessing achievement, affiliation, and power motives all at once - the Multi-MotiveGrid (MMG). Journal of Personality Assessment, 74, 126-145. 